their natural or planted range a height of at least eight feet, and in diameter of not less than two inches." This definition is not, however, allowed to exclude unbranched cactuses, yuccas and palms. The uniform recapitalization of all specific names is greatly to be commended, as also the clear type (of two sizes) and the exact illustrations. Two good maps of the region covered and a good index complete this altogether admirable publication.

\section{FUNGUS NOTES}

IN a recent number of Rhodora (January, 1908) Dr. W. J. Farlow begins the publication of "Notes on Fungi," which promise to yield critical discussions of much value. He shows that what has been known as Corticium tremellinum var. reticulatum is in the first place not a Corticium, but a Tremella, and that the variety is a distinct species, to be known hereafter as Tremella reticulata. He shows that what has been known as Synchytrium pluriannulatum (a parasite in species of Sanicula) is in reality Urophlyctis pluriannulatus, and that a uredineous parasite of Rubus neglectus and $R$. strigosus, hitherto known as, or confused with, Phragmidium gracile is Pucciniastrum arcticum var. americanum. $\mathrm{He}$ is further of the opinion that the Pucciniastrum on Potentilla bidentata is $P$. potentillae. Further notes from this source will be eagerly looked for by mycologists.

In Annales Mycologici ( $\nabla .$, No. 7, 1907) Professor F. L. Stevens figures and describes "Some Remarkable Nuclear Structures in Synchytrium." The paper is a record of facts, and the author does not attempt to base any conclusions upon what he has yet seen. Other recent fungus papers by the same author are "An Apple Rot due to Volutella" and a "List of New York Fungi" in the March and May numbers of the Journal of Mycology (1907), and "The Chrysanthemum Ray Blight" in the Botanical Gazette (October, 1907). The fungus which causes the ray blight on the chrysanthemum appears to be new and is described as Ascochyta chrysanthemi.

Heinrich Hasselbring's paper on "The
Carbon Assimilation of Penicillium" in the Botanical Gazette for March, 1908, is a contribution to our knowledge of the chemistry of the assimilation of some of the simpler compounds by plants. Among the results noted is the fact that " alcohol, acetic acid and the substances from which the acetic acid radicle $\mathrm{CH}_{3} \mathrm{COO}$ - is easily derived are assimilated by Penicellium glaucum."

Mention should be made here of Scott and Rorer's paper "Apple Leaf-spot caused by Sphaeropsis malorum" in Bulletin 121 of the Bureau of Plant Industry of the U. S. Department of Agriculture; of W. H. Lawrence's record of "Some Imported Plant Diseases of Washington," in Bulletin 83 of the Oregon Experiment Station, and Cook and Horne's "Insects and Diseases of the Orange," in Bulletin 9 of Estacion Central Agronomica de Cuba.

Here also may be mentioned Professor Harshberger's paper "A Grass-killing Slime Mould" in the Proceedings of the American Philosophical Society, Vol. XLV., recording a case in which the plasmodia of Physarum cinereum killed the blades of grass over which they had grown.

\section{Charles E. Bessey}

\section{SPECIAL ARTICLES}

SOME REMARKS ON THE CULTURE OF EASTERN NEAR-ARCTIC INDIANS

During the past summer, 1908, the writer undertook an ethnological expedition into the James Bay region of Canada, for the Department of Anthropology of the American $\mathrm{Mu}$ seum of Natural History of New York. The original intention was to journey to Moose Factory and thence to the eastern coast of the bay, touching at Rupert's House, Eastmain River and, perhaps, Fort George, at which posts it was supposed access might possibly be had to the Naskapi Indians of Labrador, who, it was thought, might come down to these points during the summer, for the purpose of trade. On arriving at Moose Factory, it was learned that the Naskapi could not be reached via the west coast of Labrador, usually known 
as Eastmain, and that they did not come out to any of the posts along that shore. At Nitchequon, a post situated in the Labrador interior, fifty-five days' journey from Rupert's House by canoe, and still in the hunting territory of the Northern Cree, the Naskapi are known to come in winter when driven by starvation. Otherwise they are confined to the interior of Labrador proper, held back on the east and north by the Esquimau, on the west by the Northern Cree, and on the south by the Montagnais.

As conditions were not favorable for study of the Naskapi, our attention was turned to the ethnology of the Northern Cree. The Northern, or perhaps more properly the Eastern, Cree range from Nitchequon on the north, south to the height of land around James Bay, west to the Albany River and Agomska Island. There are no Cree between this post and York, because the Northern Ojibway have worked northward to the coast and thus have separated the York Cree from the rest. So far as could be learned from the Hudson's Bay men and Indians, this has taken place within comparatively recent times, and it was also stated that the Western Cree came originally from the vicinity around James Bay, being induced to go westward by the Hudson's Bay Company. Both the York Cree and the Western Cree seem to be considered by the Eastern Cree to be somewhat different from the Eastern Cree, although admittedly the same people. Several dialects of their language are recognized by the eastern band, but the changes appear to be perfectly regular and phonetic, not affecting the grammar in any way.

The Eastern Cree claim to have always lived in the region that they now inhabit, and recognize several bands or subdivisions, known according to the locality which they inhabit. The Crees know themselves generally as Muskéko-wug, or "Swamp People." The social unit is the patriarchal family and there seems never to have been any clan organization among them. Village life is, and apparently was, unknown; for economic conditions caused single families to live by themselves, far apart from any others, and rendezvous was made every spring at some spot previously decided upon for the purpose of reuniting. At this time, the feasts, councils and meager ceremonies of these people were held. Nowadays, the hunters come to the Hudson's Bay posts every spring to trade their furs for supplies for the next year, and this coming together takes the place of the old spring meeting. Chiefs were never elected or chosen, but acquired their office through prestige by tacit consent on the death of the former incumbent. As the people rarely came together, excepting at the spring meetings, or in case of war, the chief's influence was small in comparison with that of the shaman. Shamanism, or "conjuring," as it is called in the north, is still quite extensively carried on for warlike expeditions, hunting, love-making and other purposes. Conjuring houses are still built and used. A shamanistic society, very loose in form, but apparently corresponding to the Midèwin of the Ojibway, occurs. There are but two degrees, and admission to these is through dreams. There are no initiatory ceremonies. So far as could be learned, members of this society do not attempt to cure disease. Apparently this is done by herb doctors.

The material culture of these people is now considerably debased through constant contact with the Hudson's Bay Company. Clothing in the old days was made of caribou skin, tanned without the hair in summer; in winter, of caribou skin with the hair, or of beaver and other furs. Garments were often made of twisted and woven rabbit skins. Coats with sleeves, hoods and mittens were worn by both sexes. The habitations consisted of conical or dome-shaped lodges, covered with painted skins, bark or brush. No mats were used for this or any other purpose, as articles of woven rabbit-skin seem the only fabrics made. Owing to climatic conditions, agriculture was unknown, a few berries furnishing the only vegetable food. Hunting, and, secondarily, fishing were the great resources of life. As hunting has not been checked, but rather given an impetus, by the advent of the Hudson's Bay Company, all the ancient superstitions regarding animal life may still be found in full force. Most interesting of these are a series 
of observances regarding the killing of the bear. While all the eastern Algonkins have observances of this order, they seem to have become much more elaborated among the Eastern Cree.

Pottery was unknown, steatite taking its place. Semilunar knives, here used as scrapers, other knives and some arrow points were rubbed out from slate. In some parts, at least, arrow points seem to have been chipped; and in others, made of bone and antler. The grooved axe was used. Basketry, except simple vessels of birch or pine bark, was unknown. Birch bark canoes were used.

Syllabics, invented by missionaries, are now used for communication in their own language, though the Cree still employ mnemonic devices of their own invention for the same purpose. Information was obtained which seemed to show that in olden times pictorial writings on birch bark, similar to those found among the Ojibways, were known. The primitive form of art seems to have been painting, and the lines employed were geometric.

Little folk-lore was collected, and this was, in the main, typically Algonkin, but some apparently resembles the Esquimau.

A comparison of the writer's notes with Lucien M. Turner's account of "The Nenenot or 'Naskopie" " Indians, ${ }^{1}$ and conference with Indians and white men who had been in the Naskapi country, seems to show that the culture of these people is identical with that of the old Cree. Considering the absence of agriculture, the lack of village life and clan systems, the loose social and political organization, the absence of pottery and the ordinary forms of fabrics, and the comparative difference of artifacts in general, as here noted-it may perhaps be well no longer to consider the region inhabited by the Eastern Cree and the Naskapi as belonging to the Eastern Woodland culture area, a region characterized throughout by its agricultural and village life, its comparatively highly developed social and political organization, its pottery, clothing

${ }^{1}$ Lucien M. Turner, "Ethnology of the Ungava District," Eleventh Annual Report, Bureau of Ethnology, 1889-90, pp. 167-350. made from skins tanned without the hair, fabrics, woven basketry, and the like. Dr. Frank G. Speck, of the Department of Archeology of the University of Pennsylvania, who spent last summer among the Montagnais of Lake St. Johns, arrived independently at the same conclusion in studying these people. It is the suggestion of the writer, then, that the culture of the region of Subarctic Eastern America inhabited by the Cree, Naskapi, and Montagnais, might better be known hereafter as the Eastern Subarctic, or Labradorean, cultural area, as it is apparently so different from the eastern woodland area with which it has hitherto been classed.

\section{Alanson Skinner \\ American Museum of Natural History}

\section{THE AMERICAN ASSOCIATION FOR THE ADVANCEMENT OF SCIENCE SECTION A-MATHEMATICS AND ASTRONOMY}

Comparatively few papers on pure mathematics appeared on the program of Section A in view of the fact that the American Mathematical Society held its annual meeting in affiliation with the association. The address of the retiring vice-president, President E. O. Lovett, the Rice Institute, Houston, Texas, was read by the secretary of the section. It was entitled "The Problem of Several Bodies, Recent Progress in its Solution," and an abstract of it has appeared in a recent number of ScIENCE.

The following members of the section were elected as fellows of the association: David R. Allen, Joseph Allen, R. B. Allen, Harriet W. Bigelow, Oskar Bolza, W. H. Bussey, B. E. Carter, E. F. Chandler, Abraham Cohen, E. H. Comstock, H. A. Converse, S. A. Corey, J. A. Cragwall, F. F. Decker, C. C. Engberg, F. C. Ferry, F. E. Fowle, Philip Fox, William Gillespie, C. C. Gore, C. O. Gunther, U. S. Hanna, A. E. Haynes, Alfred Hume, W. J. Hussey, Kurt Laves, A. H. McDougall, Max Mason, Frank E. Miller, J. S. Miller, W. F. Osgood, J. M. Page, M. T. Peed, James Pierpont, S. C. Reese, W. J. Rusk, P. L. Saurel, G. T. Sellew, E. B. Skinner, A. G. Smith, D. E. Smith, P. F. Smith, Joel Stebbins, R. P. Stephens, L. B. Stewart, H. D. Thompson, E. B. Van Vleck, Oswald Veblen, H. S. White, F. S. Woods.

The sectional committee of Section A nominated the following members of the association, 